Recorregut de recerca geològica i geoambiental per les comarques de I'Alta Segarra (Anoia) i de La Segarra: des de Calaf a Durfort, Calonge de Segarra, Castellfollit de Riubregós, a Torà i a Ivorra

Josep Maria Mata-Perelló

Joaquim Sanz Balagué

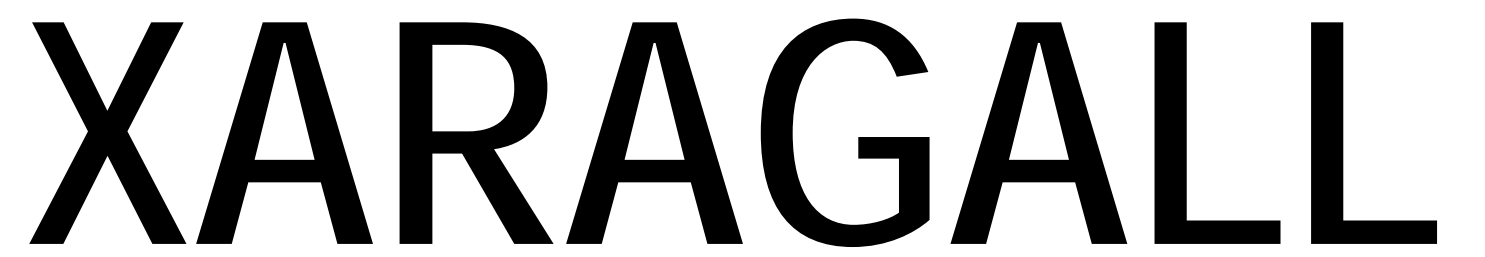

REVISTA DE CIÈNCIES DE LA CATALUNYA CENTRAL

n. 2

FEBRER 2015 


\title{
RECORREGUT DE RECERCA GEOLÒGICA I GEOAMBIENTAL PER LES COMARQUES DE L'ALTA SEGARRA (ANOIA) I DE LA SEGARRA: DES DE CALAF A DURFORT, CALONGE DE SEGARRA, CASTELLFOLLIT DE RIUBREGÓS, A TORÀ I A IVORRA
}

\author{
Josep Maria Mata-Perelló \\ Museu de geologia Valentí Masachs, Escola Politècnica Superior d'Enginyeria de Manresa \\ (EPSEM), Universitat Politècnica de Catalunya · BarcelonaTech (UPC), 08272 Manresa, Spain
}

Joaquim Sanz Balagué

Departament d'Enginyeria Minera i Recursos Naturals (EMRN), Escola Politècnica Superior d'Enginyeria de Manresa (EPSEM), Universitat Politècnica de Catalunya . BarcelonaTech (UPC), 08272 Manresa, Spain

Paraules clau: Depressió Geològica de l'Ebre, Materials terciaris, Materials quaternaris, Patrimoni miner

\section{Resum}

Itinerari realitzat el 22 de febrer de 2014. En aquesta ocasió, es realitzarà un recorregut geològic que discorrerà en la seva totalitat per diferents indrets de la Depressió Geològica de I'Ebre; i més concretament pels sectors corresponents a la seva Depressió Central. D'aquesta manera, tot el recorregut transitarà entre afloraments dels materials terciaris (de l'Oligocè) i quaternaris que reblen aquesta depressió.

Com a tret fonamental, la totalitat del recorregut transitarà per la Conca Lignitífera de l'alta Segarra, situada entre els afloraments de la Formació Tàrrega, de I'Oligocè i els del Complex Lacustre de Sanaüja.

Per altra banda, la totalitat del recorregut transitarà per la gran comarca de la Segarra; així, en un principi i quasi al llarg de tot el recorregut, anirà per la denominada Alta Segarra (que es situa dintre de la comarca d'Anoia, anant així des de Calaf fins a Castellfollit de Riubregós). Tot i així, el recorregut penetrarà finalment dintre de la Segarra estrica, finalitzant el recorregut de l'itinerari al terme d'Ivorra. 


\section{Objectius fonamentals}

Els objectius fonamentals que es pretenen aconseguir en aquest itinerari, es poden concretar en els següents aspectes generals:

1. Observació i descripció dels materials terciaris (exclusivament del Paleogen, i més concretament de l'Oligocè) de la Depressió Geològica de l'Ebre (i més exactament de la seva Depressió Central). Així, el recorregut de l'itinerari discorrerà totalment entre els afloraments del Complex Lacustre de la Segarra (amb terrenys que pertanyen a la Formació Tàrrega, de l'Oligocè, del Cenozoic). Sovint, aquests materials els veurem recoberts per altres més moderns, del Pleistocè i de l'Holocè (integrants dintre del que sovint es denomina Quaternari).

2. Observació de les estructures locals de la Depressió Geològica de l’Ebre, al llarg del recorregut de l'itinerari. Així, en alguns moments de recorregut, trobarem replegats els materials cenozoics.

3. Observació i reconeixement de les mineralitzacions associades a les alteracions de la PIRITA primària inclosa entre els nivells carbonosos de la Conca Lignitífera de I'Alta Segarra.

4. Observació de les explotacions relacionades amb els materials anteriors, com les següents, d'acord amb el sentit de la marxa de l'itinerari.

4A) Les explotacions dels nivells calcolutítics de la Formació Tàrrega, que veurem a Calaf i a Durfort, fonamentalment.

4B) Les explotacions dels materials carbonosos, que trobarem prop de Durfort, entre els materials de la Formació Tàrrega.

4C) Les explotacions dels materials carbonatats (fonamentalment de les calcolutites) del Complex Lacustre de Sanaüja, que trobarem a diversos indrets dels termes de Calonge de Segarra, Castellfollit de Riubregós i de Torà de Riubregós.

5. En tots els casos, a les explotacions anteriors, s'observaran les restauracions efectuades en elles, si s'escau.

6. S'observaran, al llarg de tot el recorregut, els diferents elements relacionats amb el Patrimoni Geològic i Miner. 


\section{Antecedents}

Pel que fa al recorregut del present itinerari, existeixen diferents antecedents bibliogràfics. Entre ells farem esment dels següents: pel que fa a la totalitat del recorregut; ja que en bona part constitueix una primícia. Hi ha, però, alguns antecedents parcials, relatiu a algun dels trama inicials; entre aquests farem esment dels següents: Mata-Perelló (1996, 1997. 1999a. 1999b, 2005, 2007a, 2007b, 2010, 2011 i 2014).

Pel que fa a la descripció de les mineralitzacions, seguirem fent esment d'alguns altres treballs nostres: Mata-Perelló (1990 i 1991); el primer relatiu a la comarca d'Anoia, el segon al conjunt de les mineralitzacions catalanes.

I, finalment, pel que fa a l'estructura geològica de la zona per la qual discorre l'itinerari, farem esment dels treballs de: GUIMERÀ et altri (1982) i de RIBA et altri (1976). També farem esment d'un treball nostre: Mata-Perelló (1985).

Tots aquests treballs referenciats, i d'altres, figuren esmentats per ordre alfabètic a l'apartat dedicat a la BIBLIOGRAFIA.

\section{Recorregut de l'itinerari}

El recorregut de l'itinerari discorrerà íntegrament per la gran comarca de la Segarra. Tot i així, bona part del recorregut transitarà per la subcomarca de I'Alta Segarra (actualment situada dintre de la comarca d'Anoia). Cap a la fi del recorregut, entrarà i finalitzarà dintre de la comarca de la Segarra (en sentit estricte), pel terme de Torà de Riubregós, concretament.

Així, el recorregut s'iniciarà al terme de Calaf (la capital de la subcomarca de l'Alta Segarra), per on es farà la primera aturada. Tot seguit, caldrà seguir per la carretera autonòmica $C$ 1412A, anant sempre cap el Nord.

Poc després, s'entrarà al terme de Calonge de Segarra; concretament a l'agregat de Durfort, per on es faran dues noves aturades (una a la bora de la carretera) i l'altra després de fer una fillola. Tot seguit, s'arribarà al propi Calonge de Segarra, per on es farà una nova aturada.

Posteriorment, caldrà continuar per la carretera C - 1412A, anant cap el proper poble de Castellfollit de Riubregós i posteriorment cap a Torà (Torà de Riubregós), des d'on es continuarà per la carretera local LV - 3003, tot fent una fillola, fins arribar prop d'Ivorra, després de fer una nova prop d'aquest darrer poble. En aquest tram, s'haurà passat de l'Alta Segarra (Anoia) a la Segarra, entre Castellfollit de Riubregós i Torà.

Després de fer aquesta fillola, es tornarà cap a Torà i cap a Castellfollit de Riubregos, amb la finalitat de fer diverses aturades, anant des d'aquest poble cap al de Durfort, per on finalitzarem el recorregut. 


\section{Advertiments previs}

Com en altres recorreguts de RECERCA GEOLÒGICA I MINERALÒGICA... si es disposa del temps suficient, poden efectuar-se passant per totes les parades i filloles. En cas contrari, recomanem prescindir de les anomenades PARADES - CONDICIONALS.

També cal tenir en conte que part del recorregut, tant a l'inici de l'itinerari, com als seus darrers trams, es realitzarà per camins de terra, per la qual cosa caldrà prendre les degudes precaucions. En aquest recorregut, caldrà fer diversos recorreguts per camins de terra en bon estat de conservació, generalment.

Cal tenir, com sempre, una cura molt especial de respecte a la natura, al llarg de tot el recorregut de l'itinerari, i també fora d'ell.

\section{Descripció de l'itinerari}

Com de costum, estructurarem el recorregut de l'itinerari en una sèrie de PARADES, que anirem veient. En cadascuna d'aquestes aturades farem un breu comentari (geològic 0 mineralògic, segons s'escaigui). En cada cas indicarem, entre parèntesi, el full topogràfic on es troba l'aturada.

En aquest cas, el recorregut de l'itinerari s'inclourà dintre de dos fulls, del "Mapa Topográfico Nacional", realitzats a I'escala 1:50.000 per I'"I.G.C. de España"; concretament del 361 (o de Cervera; encara que abans es denominava full de Guissona) i 362 (antigament dit de Calaf i ara de Sant Joan de Vilatorrada).

Tanmateix, si s'escau, es pot utilitzar el Mapa Topogràfic Comarcal d'Anoia i el Mapa Topogràfics de la Segarra, editats tots dos per I'Institut Cartogràfic de Catalunya (per I'actual Institut Cartogràfic i Geològic de Catalunya).

Així doncs, la relació de les aturades, que composen el recorregut d'aquest itinerari és la següent:

\subsection{Parada 1. EXPLOTACIONS DE CALCOLUTITES DEL TURÓ DE SANT SEBASTIÀ, (terme municipal de Calaf, comarca d'Anoia, subcomarca de I'Alta Segarra). (Full 362).}

El recorregut de l'itinerari l'iniciarem al bell mig de la població de Calaf (la capital de la subcomarca). En concret, l'iniciarem molt prop de les antigues instal-lacions de Ceràmiques Calaf. En aquest indret, prop de les explotacions, farem la primera aturada.

En aquest lloc, aquests es trobava una explotació de calcolutites, per tal d'ésser utilitzats en la fabricació de totxos i de ceràmica. Pel que fa a l'explotació, cal dir que era força gran, i els materials extrets es portaven cap a la propera fàbrica, situada a la bora de Calaf. Aquest indret es troba dintre de la Depressió Geològica de l'Ebre, entre els afloraments de la Formació Tàrrega.

També, cal dir que prop de l'explotació es troba un "parc" amb argiles i calcolutites de diverses procedències, per tal d'ésser emprades a la fàbrica. Finalment, cal dir que per accedir a l'explotació, cal tenir necessàriament l'autorització de l'empresa (Ceràmiques Calaf S.A.), tot i estar actualment aturada. (fotografia 1).

Xaragall.2015 n.2 | Recorregut de recerca geològica i geoambiental per les comarques de l’Alta Segarra 


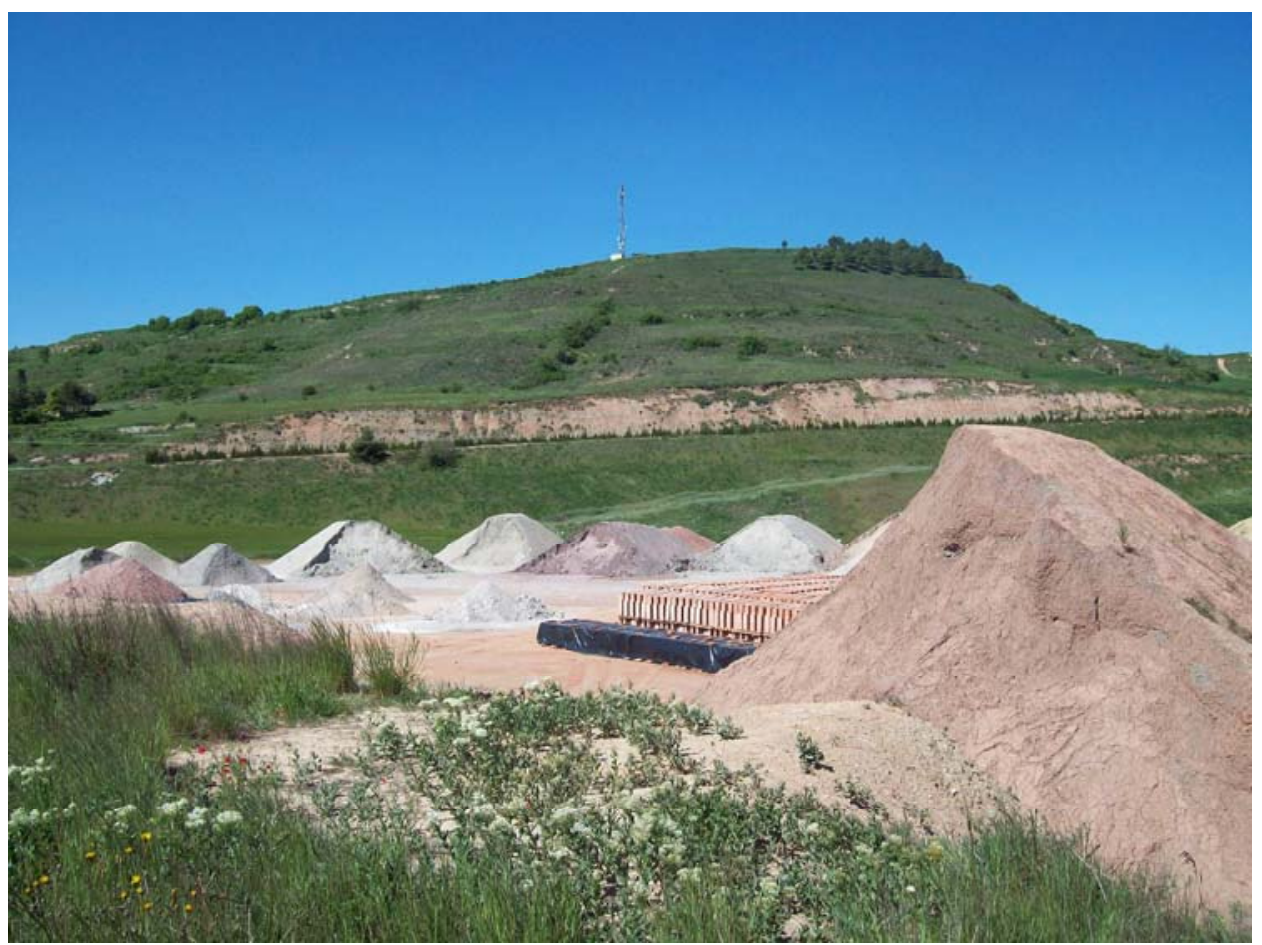

Fotografia 2. Vista general de Ceràmiques Calaf. Es poden veure argiles procedents de diferents indrets. Calaf

\subsection{Parada 2. MINA DE CARBÓ DE LES IMMEDIACIONS DEL CAL FRARE, (Durfort, terme municipal de Calonge de Segarra, comarca d'Anoia, subcomarca de l’Alta Segarra). (Full 362).}

Després de realitzar l'aturada anterior, cal sortir de Calaf cap el Nord, per la carretera autonòmica $C$ - 1412A. En sortir del poble, trobarem una cruilla amb l'Eix transversal, però nosaltres continuarem cap el Nord (cap a Ponts). Aviat arribarem a les instal-lacions tancades de Gres Catalan (a la dreta de la carretera) i de Ceràmiques Sugranyes (a l'esquera). Prop de la primera, trobarem un camí asfaltat que puja cap a Durfort. Tot i això, nosaltres seguirem cap al Nord. Poc després (a uns 150 me del poble acabat d'esmentar), trobarem per la dreta un camí en bon estat, que acaba baixant cap a una riera. En arribar baix, trobarem les instal-lacions d'una antiga mina de lignit. Aquí, farem una nova aturada, a uns $2 \mathrm{Km}$ de I'anterior.

En aquest recorregut, hem anat trobant afloraments dels materials de la Formació Tàrrega, de I'Oligocè. Així, haurem vist per arreu, nivells de calcolutites (grises i ocres) i també nivells de calcaries. Ocasionalment, com prop de l'indret de la present aturada, haurem vist nivells de calcaries, com succeeix prop de l'indret de l'aturada.

En aquest lloc hi ha les instal-lacions d'una antiga explotació del lignits inclosos entre els materials de la Formació Tàrrega. Entre els lignits es troben sulfurs de ferro (PIRITA i MARCASSITA), alterats a òxids de ferro (GOETHITA, en forma de LIMONITA) i a sulfats de ferro (MELANTERITA): 
Així, aquí es veuen restes dels edificis miners i de les bocamines, però en un lamentable estat de conservació; tot i així, son elements del Patrimoni Miner de la comarca de l'Alta Segarra. (fotografia 2).

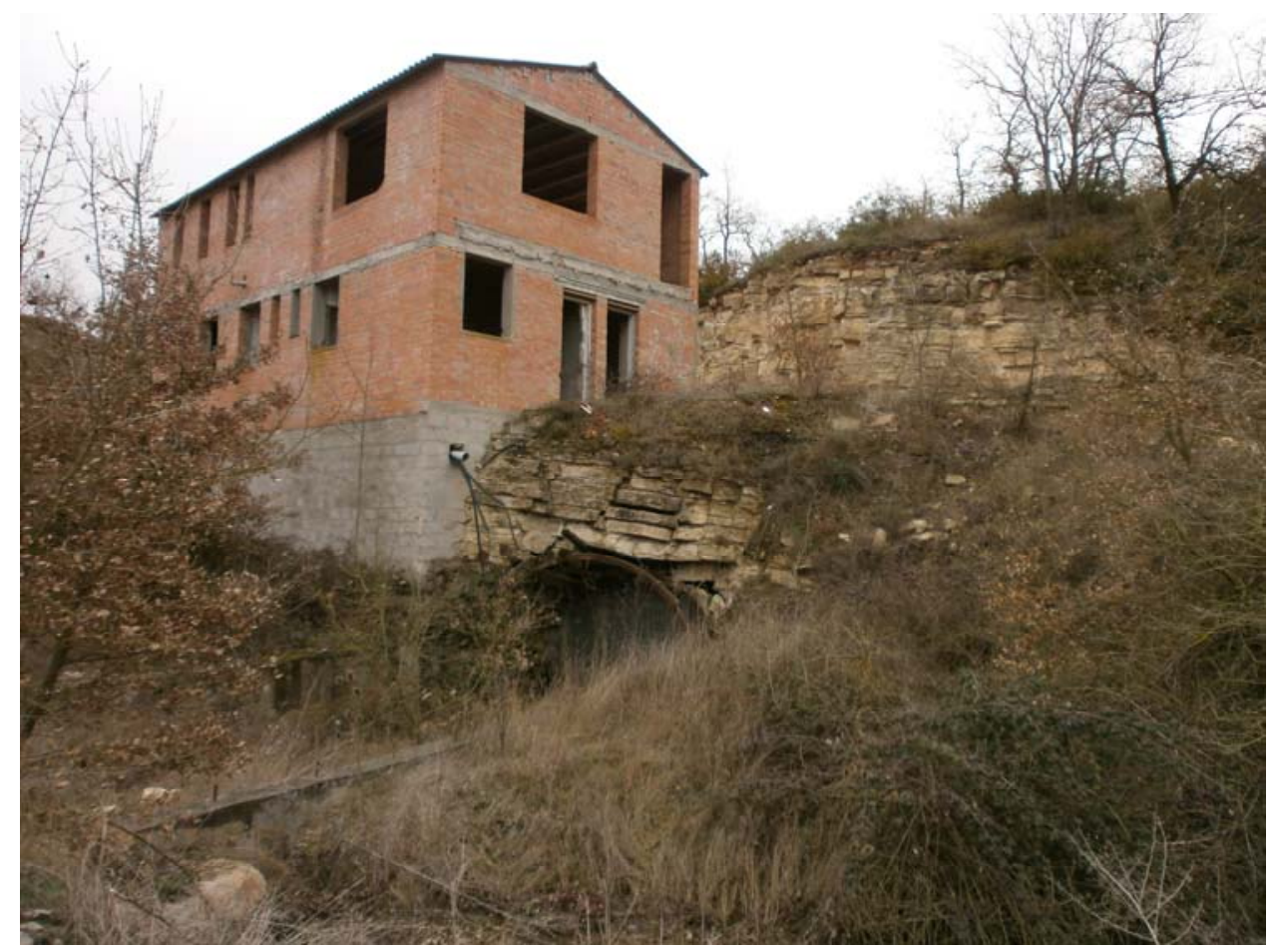

Fotograifa 2. Restes de les instal-lacions de la mina de lignit de Cal Frare. Durfort

També cal dir que al llarg del present recorregut, s'hauran fet palesos per arreu els típics relieves en cuesta. Tanmateix, haurem observat com inicialment ens hem situat al flanc septentrional del Sinclinal de Calaf, en funció de la lleugera inclinació cap el Sud dels materials, tot i que ben aviat hauran passat a tindre un cabussament septentrional.

\subsection{Parada 3. IMMEDIACIONS DEL TURÓ DEL CASTELL DE CALONGE DE SEGARRA, (terme de Calonge de Segarra, comarca d'Anoia, subcomarca de I'Alta Segarra). (Full 362).}

Després de realitzar la parada anterior, cal retornar cap a al camí que hem agafat a la població de Durfort. En trobar-lo continuarem cap el Nord, apropant-nos a Cal Groga i posteriorment a Calonge de Segarra. Des d'aquí, ens caldrà baixar cap a la carretera autonòmica C - 1412A, però farem una aturada a la vessant occidental del turó on es troba el Castell de Calonge. Així, des de la parada anterior, haurem recorregut poc menys de $2 \mathrm{Km}$, per tal d'arribar fins aquí.

En aquest recorregut, hem anat trobant afloraments dels materials cenozoics esmentats a les aturades anteriors. Tot i així, en baixar des del turó del castell, haurem començat a trobar afloraments dels nivells del Complex Lacustre de Sanaüja, amb calcolutites i guixos. Aquests darrers són els afloren al peu del turó. Aquests guixos són equivalents laterals als denominats Guixos de Barbastro i també a la Formació Súria. 
Per altra banda, aquests materials, concretament els guixos, es troben força inclinats, en formar part del flanc meridional de l'extrem occidental de l'Anticlinal de Cardona. (fotografia 3).

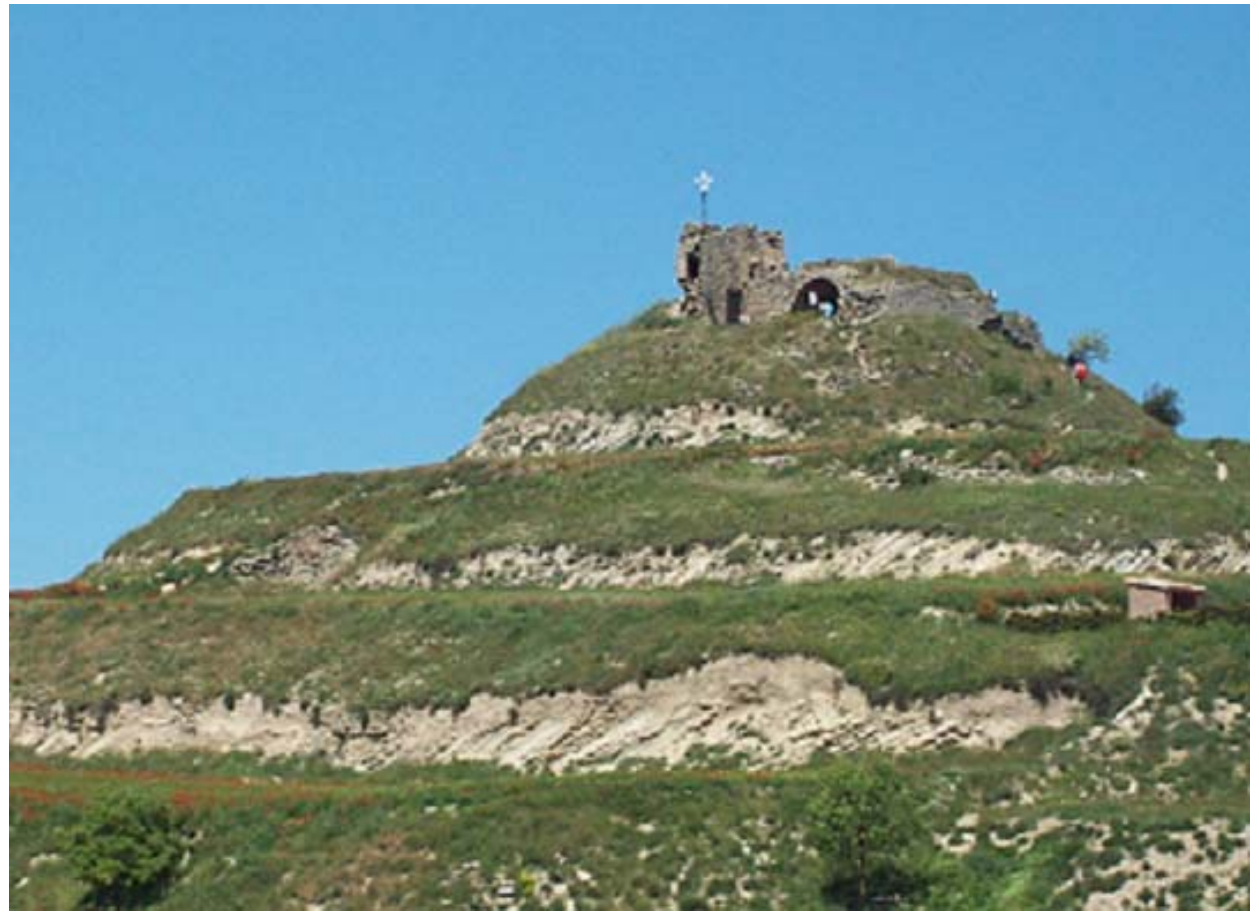

Fotografia 3. Un aspecte del turó del Castell de Calonge de Segarra

A la base apareixen els guixos del Complex Lacustre de Sanaüja, molt inclinats

\subsection{Parada 4 - CONDICIONAL. TRENCALL D’ENFESTA, DE LA CARRETERA C - 1412A, (terme municipal de Castellfollit de Riubregós, comarca de l'Anoia, Subcomarca de l'Alta Segarra). (Full 361).}

Després de realitzar la parada anterior, ens cal acabar d'arribar fins a la carretera autonòmica C - 1412A. En trobar-la, I'haurem d'agafar en el seu sentit septentrional, anant cap al proper poble de Castellfollit de Riubregós. En arribar al trencall d'Enfesta, per la dreta de la carretera, podem fer una nova aturada. Així, des de l'anterior, haurem recorregut poc més de 3 $\mathrm{Km}$. En aquest recorregut, passarem per indrets per on farem algunes aturades a la tornada.

En aquest recorregut, haurem trobat afloraments dels materials esmentats a l'aturada anterior, els quals formen part del Complex Lacustre de Sanaüja. Per d'altra banda, estarem ara circulant per l'eix de l'Anticlinal de Sanaüja. Es tracta d'un anticlinal desventrat, circulant el riu Bregós pel seu nucli.

En aquest indret, i també pels voltants de Castellfollit, hi ha un extens aflorament dels guixos que hem comentat a l'aturada anterior. (fotografia 4). 


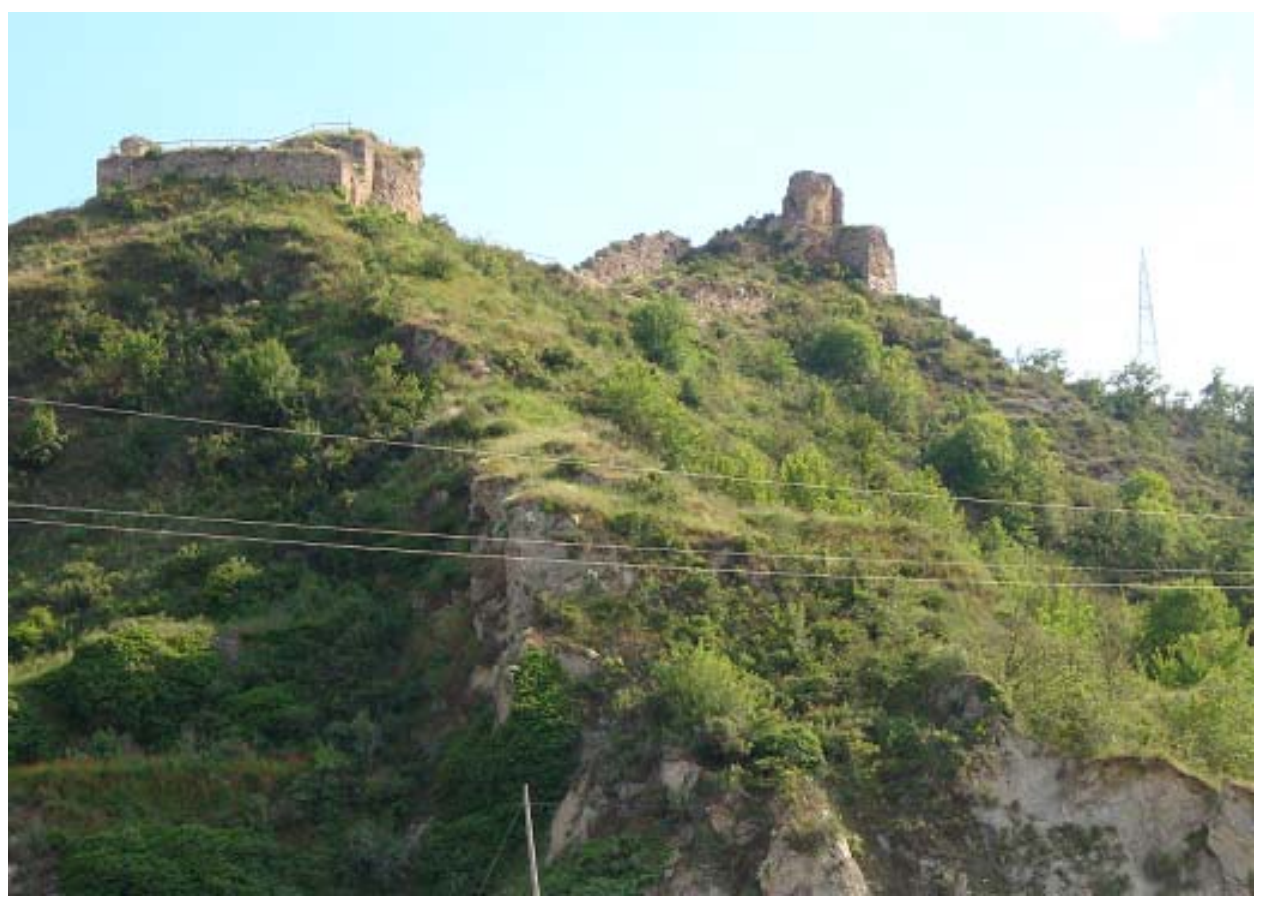

Fotografia 4. El Castell de Castellfollit de Riubregos, amb afloraments de guixos a la seva base

\subsection{Parada 5. ANTIGA FÀBRICA DE CIMENT ROCA, (terme municipal d'Ivorra, comarca de la Segarra). (Full 362).}

Després de realitzar la parada anterior, cal acabar d'arribar fins el poble de Castellfollit de Riubregos, per tal de continuar per la carretera autonòmica C - 1412A. que es dirigeix ara cap a Torà. Quasi a l'entrada d'aquest darrer poble, trobarem la carretera local LV - 3003 (procedent de Sant Ramon). Ens caldrà agafar-la, per tal d'apropar-nos a Ivorra. Poc abans d'arribar-hi, trobarem a ma esquerra les instal-lacions d'una antiga fàbrica de ciment. En aquest indret ens caldrà fer una nova aturada, a uns $3 \mathrm{Km}$ de Torà i a uns $8-9 \mathrm{Km}$ de la parada anterior. Com al recorregut anterior, en aquest recorregut, passarem per indrets on farem aturades a la tornada. Per d'altra banda, en aquest recorregut, entre Castellfollit i Torà, hem deixat I'Alta Segarra, per entrar a la comarca de la Segarra, on som ara,

En aquest recorregut, hem anat trobant afloraments dels materials del Complex Lacustre de Sanaüja, fonamentalment els nivells de calcolutites i els de guixos. Aquests darrers s' hauran fet molt palesos a diferents trams del recorregut, com pels voltants de la població de Torà.

En aquest indret hi ha un important complex patrimonial, al qual no es troba en bon estat de conservació, tot i que encara es troba en peus. Es tracta de la Fábrica de cementos, yesos y cales Roca. Aquí es tractaven les calcolutites extretes a les proximitats, per a l'obtenció de ciment ràpid. (fotografia 5). 


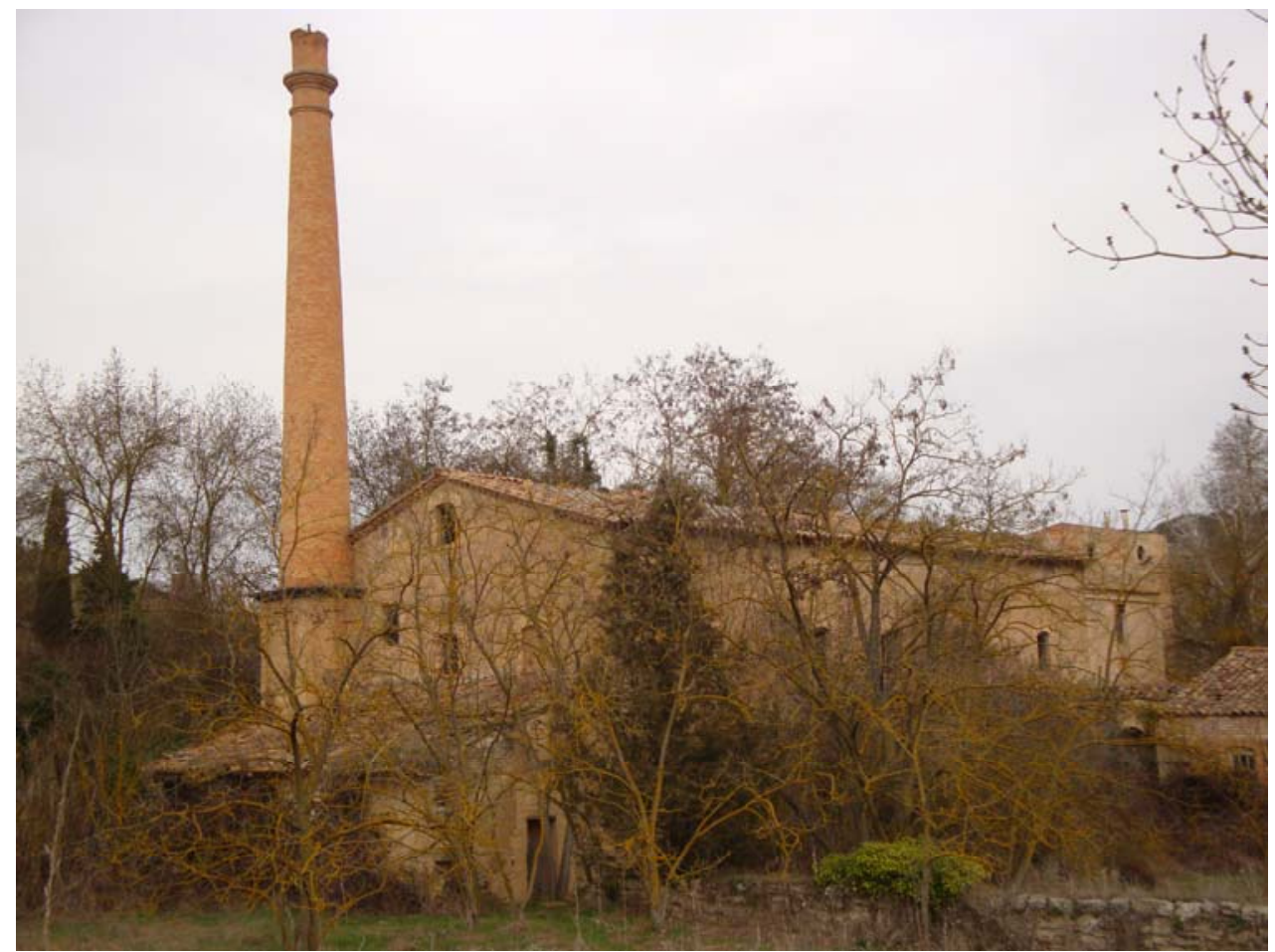

Fotografia 5. Un aspecte de la Fàbrica Roca, de ciments ràpids. Ivorra

\subsection{Parada 6 - CONDICIONAL. PEDRERA D'IVORRA, (terme municipal d'Ivorra, comarca de la Segarra). (Full 361).}

Després de fer l'aturada anterior, hi ha la possibilitat de fer un curt recorregut cap a l'actual Pedrera d'Ivorra. En cas d'anar-hi, demanant el permís corresponent, ens caldrà fer un recorregut proper a uns $200-300$ metres, per camins de terra.

En aquest recorregut, passarem al costat d'uns antics Forns de Calç (fotografia 6) i finalment arribarem a la pedrera. En aquesta s'exploten calcolutites grisenques del Complex Lacustre de Sanaüja, per tal d'esser emprades per a I'obtenció de cal en una fàbrica d'Ivorra molt propera a Castellfollit de Riubregós, des d'on s'hi accedeix. 


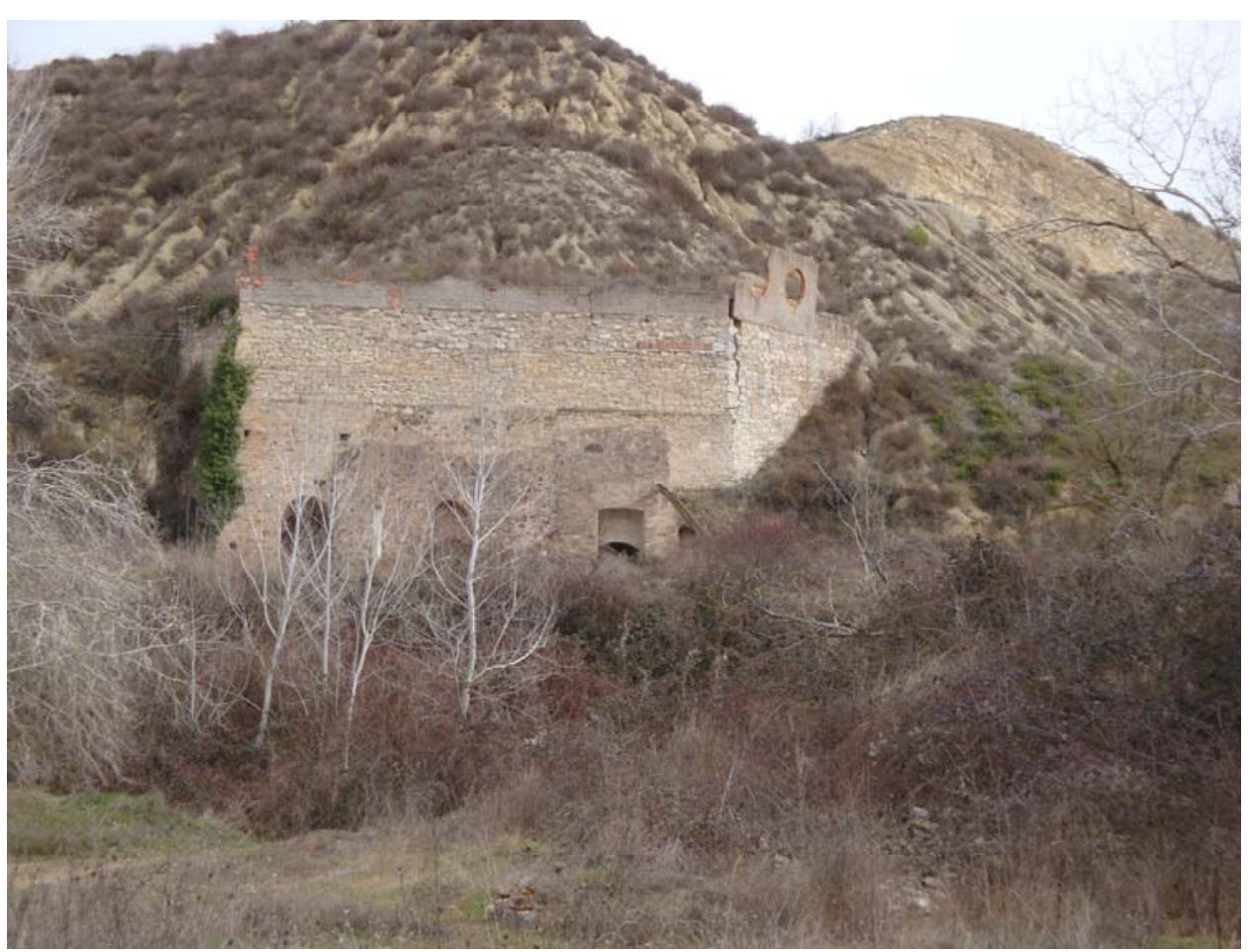

Fotografia 6. Detall dels Forns de calç. Al fons es veu la Pedrera d'Ivorra

En aquesta pedrera, entre els nivells de calcolutites, es relativament fàcil obtindré bones mostres cristal-litzades de CALCITA i especialment de CELESTINA. Tot i així, per entrar a la pedrera, cap demanar i obtenir I'autorització corresponent.

\subsection{Parada 7. ANTIGA FÀBRICA DE CIMENT DE U.M.S.A, (terme municipal de Castellfollit de Riubregós, comarca d'Anoia, subcomarca de I'Alta Segarra). (Full 361).}

Després de fer les dues aturades anteriors, cal retornar cap el proper poble de Tora (utilitzant de nou la carretera LV - 3003), per després retornar cap a Castellfollit de Riubregós (com abans per la carretera C - 1412A). Així, haurem completat una fillola. En arribar al trencall d'aquest darrer poble (per la dreta de la carretera) ens caldrà agafar-lo momentàniament, sense passar a I'altra banda del pont. En efecte, trobarem un camí de terra paral.lel a la carretera. Agafant-lo, passarem per sota de la mateixa, arribant a una antiga fàbrica de ciment ràpid (U.M.S.A.). Aquí farem una nova aturada, a uns $8 \mathrm{Km}$ de la parada anteriorment realitzada. Cal dir que des de la parada anterior, podíem vindre per un camí de terra, passant per la fàbrica on es tracten els materials estrets a la pedrera. Aquest camí, en el darrer tram es converteix en una carretera.

En aquest recorregut. Hem tornat a trobar els materials esmentats als recorreguts anteriors; concretament els guixos i les calcolutites del Complex Lacustre de Sanaüja. Així, prop de Castellfollit, es faran força palesos els nivells de guixos, mentre que a l'indret de l'aturada es fan molt palesos els nivells de les calcolutites. Precisament, aquests són els materials explotats prop d'aquest lloc. 
Així, on ara som, es fan paleses les instal-lacions de l'antiga fàbrica de l'empresa U.M.S.A. En aquesta s'utilitzaven les calcolutites explotades per a la fabricació de ciment ràpid. Les instal-lacions es troben en un relatiu bon estat de conservació i formen part del Patrimoni Miner de la comarca de l'Alta Segarra. (fotografia 7).

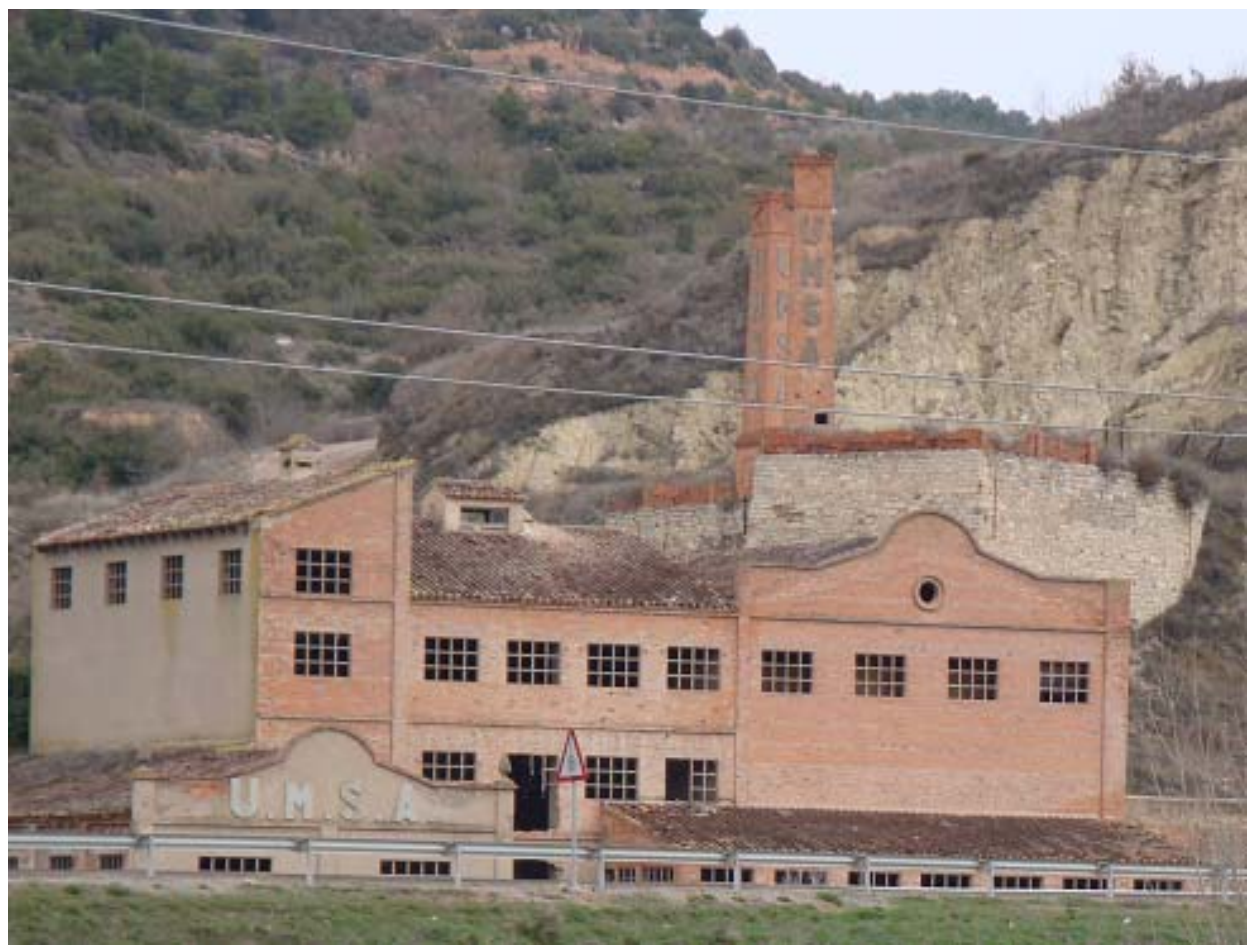

Fotografia 7. Instal-lacions de la fàbrica U.M.S.A. Al darrera hi ha una de les explotacions de calcolutites que abastien la fàbrica, per a la fabricació de ciments ràpids. Castellfollit de Riubregós

\subsection{Parada 8. IMMEDIACIONS DE L'ANTIGA FÀBRICA DE CIMENT DE LA CASA BLANCA, LO TOSSAL, (terme municipal de Calonge de Segarra, comarca de I'Anoia, subcomarca de I’Alta Segarra). (Full 361).}

Després de realitzar la parada anterior, caldrà retornar a la carretera autonòmica $C$ - 1412A, amb la finalitat d'anar cap a Durfort, cap a Calaf. Així, passarem pel trencall d'Enfesta (on hem fet una parada, la 4, en anar en sentit invers). Ara, ens caldrà arribar fins als voltants de la Casa Blanca, per on hi ha el $\mathrm{Km} 31$ de la carretera. Aquí farem una nova aturada, a uns 2' $5 \mathrm{Km}$ de l'anterior.

En aquest recorregut, hem anat trobant els materials esmentats anteriorment: els guixos i les calcolutites del Complex Lacustre de Sanaüja. Precisament, prop del Km 31, es pot veure una interessant estructura entre els afloraments dels guixos. (fotografia 8).

Per altra banda, a l'altra banda de la carretera, es fan molt evidents les restes d'una antiga fàbrica de ciment. Tot i això, hi ha un accés difícil (per la presencia de la carretera). Aquestes instal-lacions es poden veure molt be a uns 150 metres de la Casa Blanca, anant cap a Calaf. (fotografía 9). 


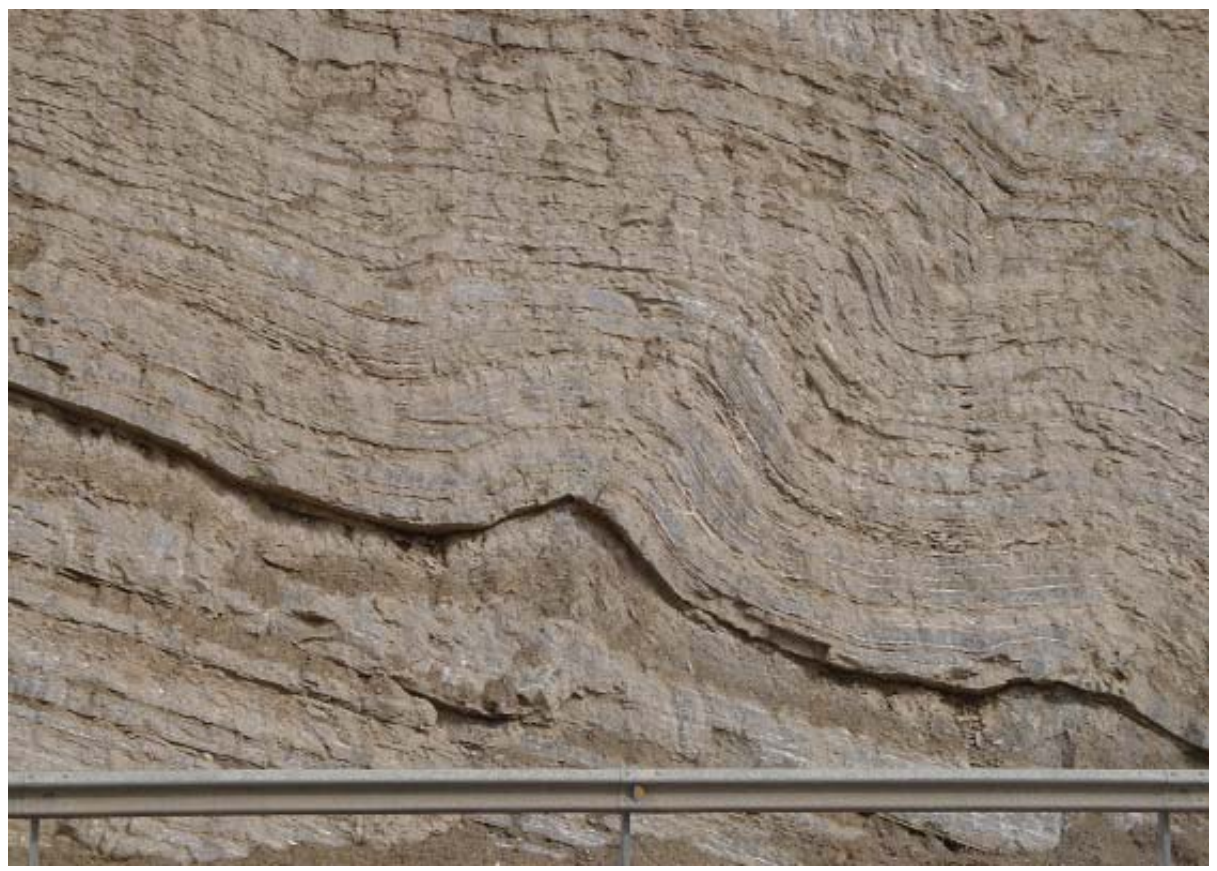

Fotografia 8. Afloraments del guixos del Complex Lacustre de Sanaüja, prop del Km 31 de la C - 1412A

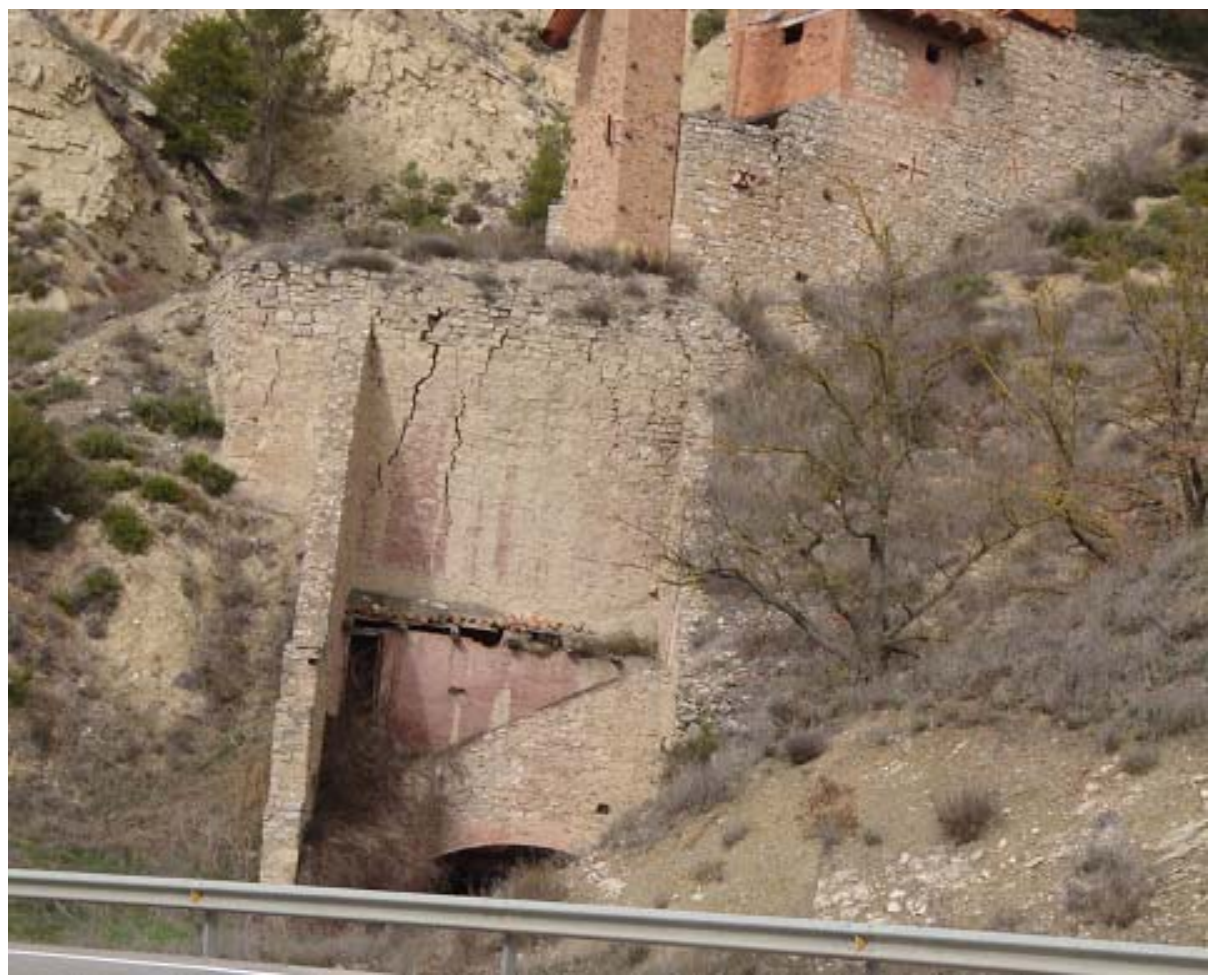

Fotografia 9. Restes de les instal-lacions de la fàbrica de ciment ràpid de lo Tossal. Calonge de Segarra

Xaragall.2015 n.2 | Recorregut de recerca geològica i geoambiental per les comarques de l'Alta Segarra (Anoia) i de La Segarra: des de Calaf a Durfort, Calonge de Segarra, Castellfollit de Riubregós, a Torà i a Ivorra 


\subsection{Parada 9. ANTIGA FÀBRICA DE CIMENT DE SANTA MARGARIDA DE LA VALL, (Santa Margarida de la Vall, terme municipal de Calonge de Segarra, comarca d'Anoia, subcomarca de I’Alta Segarra). (Full 361).}

Després d'efectuar I'aturada anterior, cal seguir per la carretera C - 1412A, la qual es va dirigint cap a Calaf. Poc després de sobrepassar el trencall de la carretera que baixa de Calonge de Segarra (que arriba per l'esquerra, per on hem vingut anteriorment, entre la segona i la tercera parada), trobarem un trencall per la dreta, que es dirigeix cap a unes antigues instal-lacions d'una fàbrica de ciment ràpid. En trobar aquesta carretereta, ens caldrà agafar-la, anant així cap aquestes instal-lacions. En arribar-hi, farem una nova aturada, a uns 1'2 Km de la parada anterior.

En aquest recorregut, hem anat trobant els materials que ja hem esmentat a les aturades anteriors. Aquests materials han estat aquí explotats, per tal d'esser emprats com a matèria prima per a la fabricació de ciment ràpid. Precisament, aquí hi ha les restes d'un antic complex industrial, dedicat a l'obtenció de ciment ràpid a partir de les calcolutites. Aquest complex forma part del Patrimoni Miner de la comarca de l'Alta Segarra, malgrat el seu estat de conservació (a causa d'això, cal tindre molta cura en visitar-lo, per l'evident risc d'esfondrament). (fotografia 10).

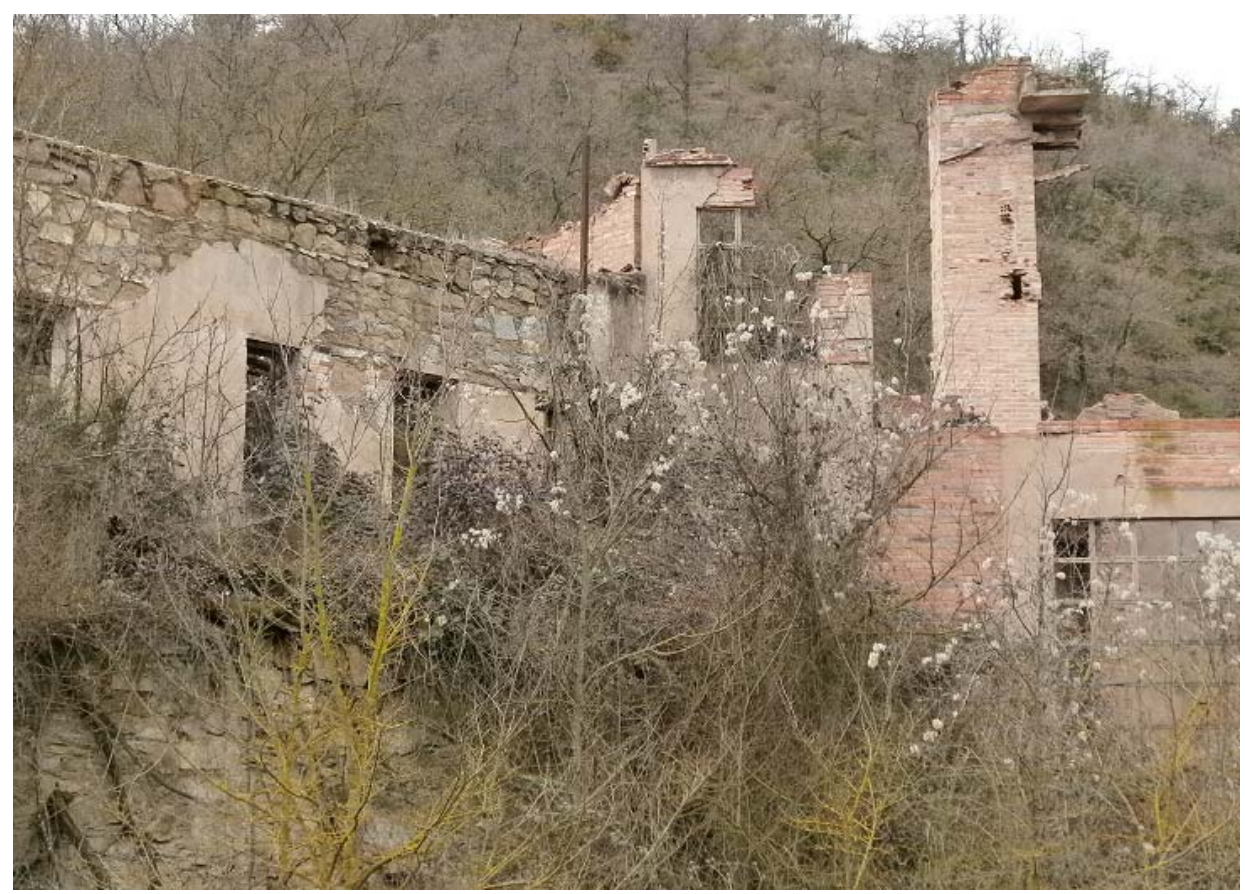

Fotografia 10. Instal-lacions de la fàbrica de ciment ràpid del camí de Santa Margarida de la Vall 


\subsection{Parada 10. TRENCALL DEL SOLEI, CARRETERA C - 1412A, (el Solei, pertany al terme de Calonge de Segarra, comarca d'Anoia, subcomarca de I’Alta Segarra). (Full 361).}

Una vegada efectuada l'anterior aturada, cal seguir cap a Calaf, per la carretera autonòmica $C$ - 1412A. En arribar al trencall del Solei, podem efectuar una nova aturada. Així, haurem efectuat un recorregut proper als $1^{\prime} 5 \mathrm{Km}$, prop del $\mathrm{Km} 32^{\prime} 6$ de la carretera. Aquí mateix, farem una nova aturada.

En aquest recorregut, hem continuat trobant inicialment els materials calcolutítics i guixosos del Complex Lacustre de Sanaüja. Tot i així, ben aviat començarem a trobar els nivells de calcolutites, gresos ocres i rogencs de la Formació Tàrrega, amb intercalacions carbonatades de calcàries. Aquests materials són els que es troben a l'indret de l'aturada.

Precisament, prop de l'indret de la present aturada, es faran paleses dues fractures entre els materials de la Formació Tàrrega que anem trobant al llarg del present recorregut. Aquestes fractures es fan força paleses, des de l'inici del camí cap el Solei, a la vora de la carretera. Tot i això, l'observació no és gaire bona, en trobar-se una xarxa metàl-lica per evitar despreniments sobre la calçada. (fotografia 11).

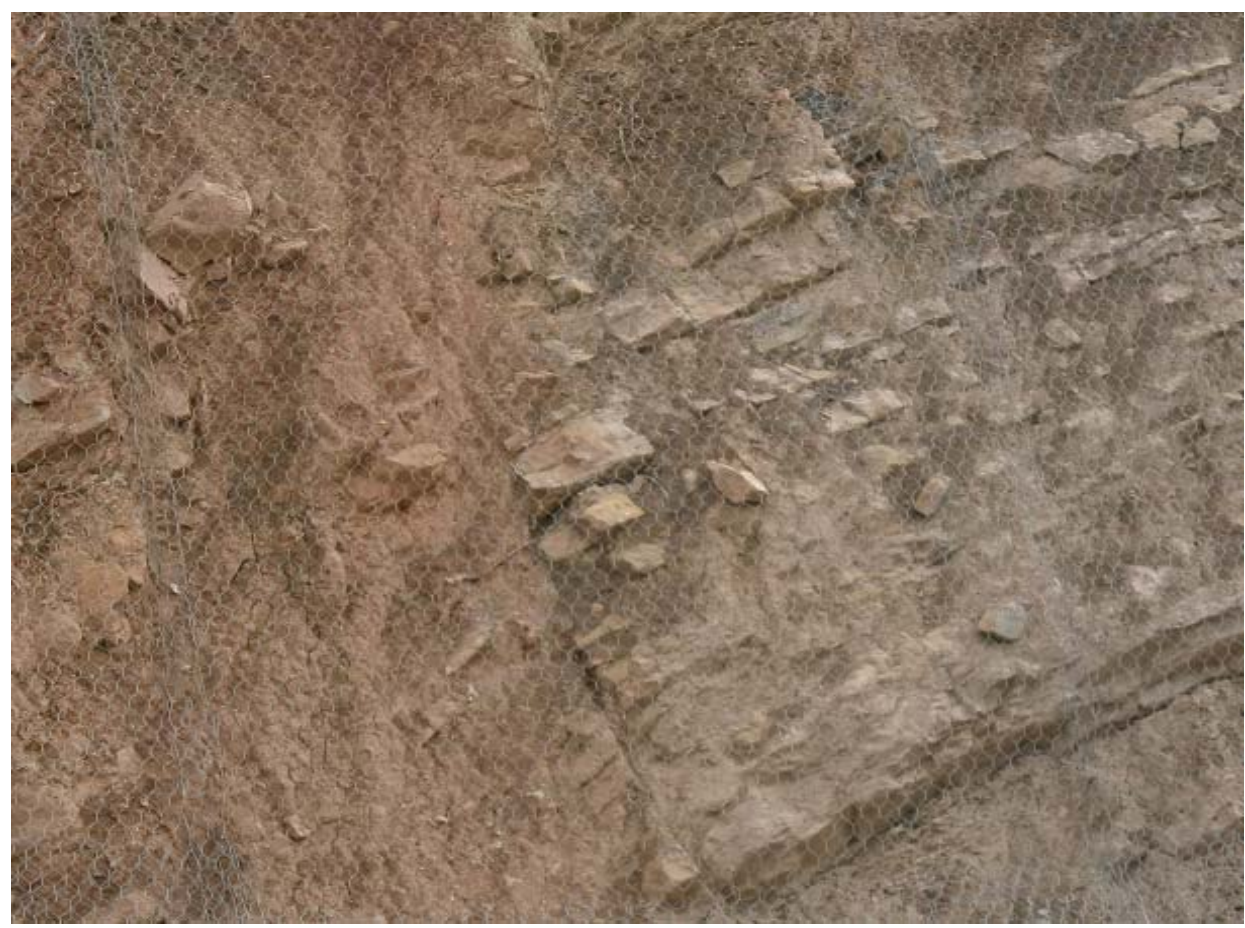

Fotografia 11. Fractura entre els materials de la Formació Tàrrega. Trencall del Solei. Durfort 


\subsection{Parada 11. INSTAL-LACIONS DE L'ANTIGA BÒVILA DE DURFORT, (Durfort, pertany al terme de Calonge de Segarra, comarca d'Anoia, subcomarca de I’Alta Segarra). (Full 362).}

Després de realitzar la parada anterior, cal continuar cap a Durfort i cap a Calaf, seguint sempre la carretera autonòmica C - 1412A. En arribar front al trencall de Durfort, ens caldrà fer una nova aturada, la darrera del recorregut, a la bora de la carretera. Així, des de I'anterior, haurem efectuat un recorregut proper als $3^{\prime} 5 \mathrm{Km}$.

En aquest recorregut, hem continuant trobant els materials de la Formació Tàrrega; així haurem vist nivells de calcolutites ocres (lleugerament rogenques) i de gresos. Ocasionalment, haurem trobat alguns nivells carbonatats de calcàries. Aquests materials es troben replegats prop del $\mathrm{Km} \mathrm{35}$, formant un sinclinal de molt difícil observació. (fotografia 12).

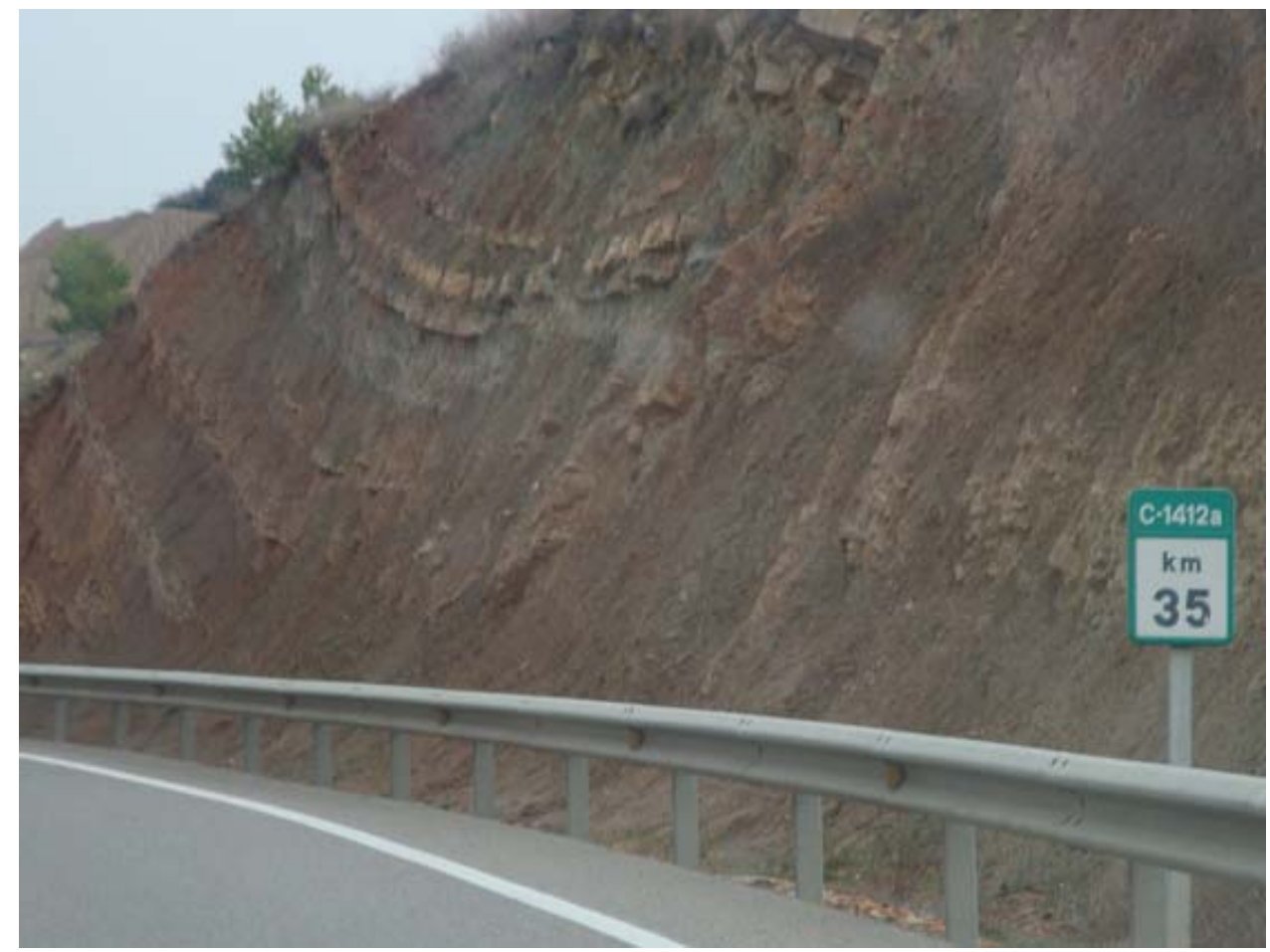

Fotografia 12. Sinclinal entre els materials de la Formació Tàrrega. Durfort 


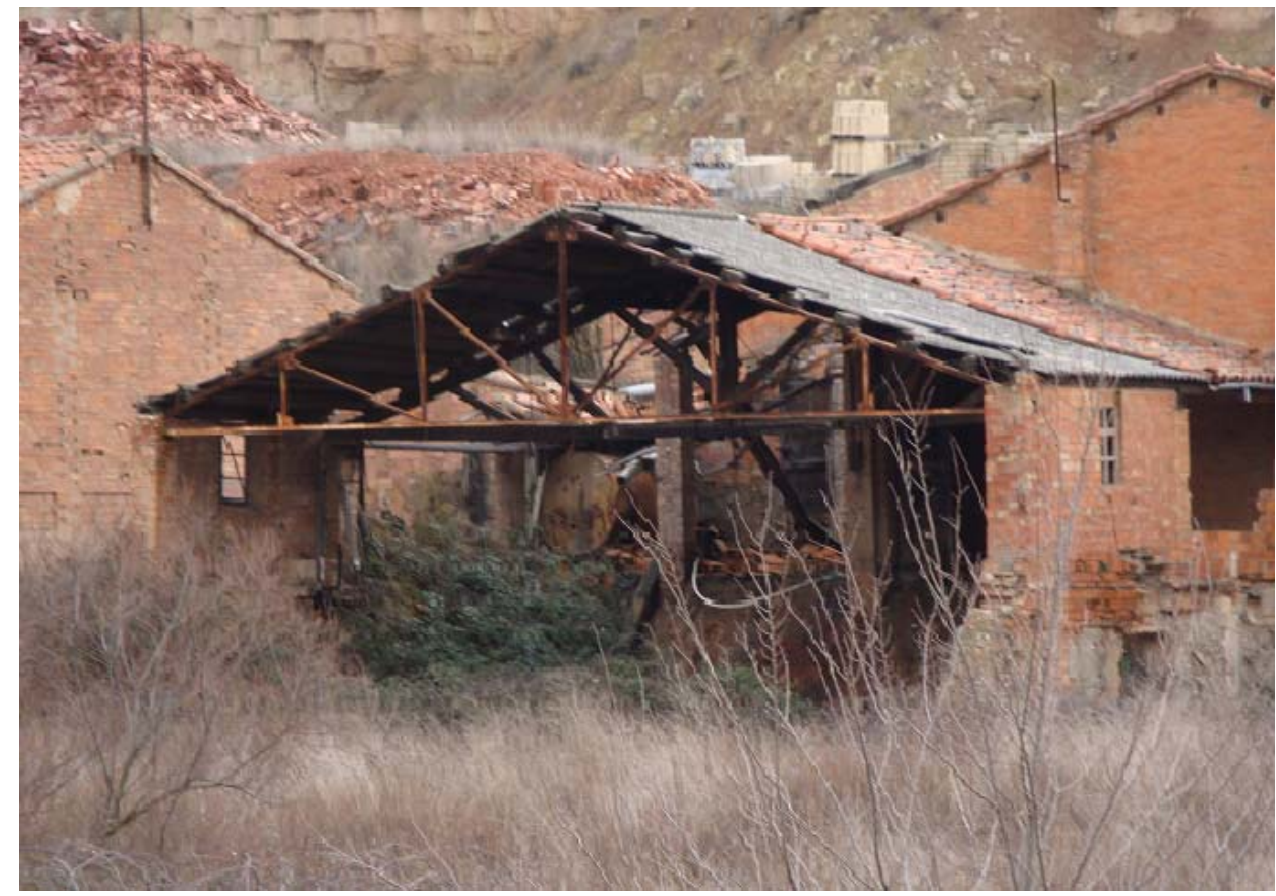

Fotografia 13. Restes de les antigues instal-lacions de Ceràmiques Sugranyes. Durfort

Així, en aquest recorregut, haurem vist els afloraments de calcolutites, gresos i calcaries abans esmentats. També cal dir que ocasionalment es troben nivells de lignits. Precisament, prop de Durfort (a uns 200 metres) per sobre de la carretera, es veuran uns nivells de lignits, els quals són molt radioactius. Al respecte d'aquests lignits (molt similars als de la parada anterior), també cal dir que van ésser explotats molt prop de la població.

En aquest recorregut, com en tots els que hem anat efectuant, ens trobem sempre dintre de la Depressió Geològica de l'Ebre. No cal oblidar que la totalitat del recorregut de l'itinerari, I'efectuarem dintre d'aquesta unitat geològica, entre afloraments cenozoics de l'Oligocè, majoritàriament.

Des d'aquest indret, podem veure les antigues instal-lacions de Ceràmiques Sygranyes, situades per sota de la fàbrica recentment tancada. Aquestes instal-lacions (molt mal conservades) formen part del Patrimoni Miner de l'Alta Segarra. (fotografia 13).

Per altra banda, prop d'aquestes es troben les instal-lacions actuals (ata tancades) i les del Gres Catalan a l'altra banda de la carretera (també tancades).

En aquest indret finalitza el recorregut de l'itinerari.

Xaragall.2015 n.2 | Recorregut de recerca geològica i geoambiental per les comarques de l’Alta Segarra (Anoia) i de La Segarra: des de Calaf a Durfort, Calonge de Segarra, Castellfollit de Riubregós, a Torà i a Ivorra 


\section{Bibliografia}

GUIMERÀ, J. et altri (1992).- Geologia (II), Història Natural dels Països Catalans, Vol.2, 547 pag. Enciclopèdia Catalana, S.A. Barcelona.

MATA - PERELLÓ, J.M. (1985).- Depressió de l'Ebre ?, Depressió Central ?. Revista Dovella, $\mathrm{n}^{\circ} 15$, pp.. $45-48$. Manresa.

MATA-PERELLÓ, J.M. (1990).- Inventari Mineralògic de la comarca d'Anoia. Revista Xaragall, $\mathrm{n}^{\circ} 24,40$ pag. Manresa.

MATA-PERELLÓ, J.M. (1991).- Els Minerals de Catalunya. Arxius de la Secció de Ciències, t. XCIII, 442 pag. Institut d’Estudis Catalans. Barcelona.

MATA-PERELLÓ, J.M. (1996).- Recerca geològica i mineralògica per I'Anoia, la Segarra i el Solsonès: de Calaf a la Molsosa i a Torà. Algeps, sèrie $B, n^{\circ} 9,11$ pàg. Manresa.

MATA-PERELLÓ, J.M. (1997).- Recorregut de recerca geològica i mineralògica per la Segarra i per l'Alta Segarra (Anoia): des de Sant Martí de Sesgueioles a Calaf i a Torà de Riubregós. Inèdit, 17 pàgines. Manresa.

MATA-PERELLÓ, J.M. (1999a).- Recerca geològica per les comarques del Bages i de I'Anoia: des de Castellfollit de Riubregós a Rajadell i a Calaf. Algeps, sèrie $B, \mathrm{n}^{\circ} 118,11$ pàgines. Manresa.

MATA-PERELLÓ, J.M. (1999b).- Recorregut de recerca geològica i mineralògica per les comarques del Bages, Alta Segarra i Anoia. Des de Rajadell a Calaf i a Ivorra, Inèdit. 14 pàg. Manresa.

MATA-PERELLÓ, J.M. (2005).- Recerca geològica, minera i mineralògica per les comarques de I'Alta Segarra (Anoia) i de la Segarra: des de sant Martí de Sesgueioles a Calaf; i des de Durfort a Sant Ramon. Inèdit. 8 pag. Manresa.

MATA-PERELLÓ, J.M. (2007a).- Recorregut de recerca geològica, minera i mineralògica per les comarques de l'Alta Segarra (Anoia) i de la Segarra: des de Sant Martí de Sesgueioles a Calaf; i des de Durfort a Castellfollit de Riubregós, Ivorra i a Sant Ramon. Inèdit. 8 pàgines. Manresa.

MATA-PERELLÓ, J.M. (2007b).- Recorregut de recerca geològica, minera i mineralògica per les comarques de l'Anoia, l'Alta Segarra calafina (Anoia) i de la Segarra: des de la Panadella a Sant Martí de Sesgueioles, Calaf, Durfort i a Castellfollit de Riubregós. Inèdit. 10 pàgines. Manresa.

MATA-PERELLÓ, J.M. (2010).- Recorregut de recerca geològica, minera i mineralògica per les comarques de l'Alta Segarra Calafina (Anoia) i de la Segarra: des de Sant Martí de Sesgueioles a Calaf; i de Durfort a Castellfollit de Riubregós, Torà de Riubregós i a Ivorra. Inèdit. 16 pàgines. Manresa.

MATA-PERELLÓ, J.M. (2011).- Recorregut de recerca geològica, minera i mineralògica per la comarca de I'Alta Segarra Calafina (Anoia): des de Sant Martí de Sesgueioles a Calaf; i des de Durfort a Castellfollit de Riubregós. Inèdit. 12 pàgines. Manresa.

MATA-PERELLÓ, J.M. (2014).- Recorregut de recerca geològica i geoambiental per la comarca d'Anoía (Alta Segarra), tot fent una fillola final pel Solsonès: des dels Prats de Rei a Calaf, Durfort, Aleny, Sant Pesselaç i a les Basses. Inèdit. 14 pàgines. Manresa. 
XAPAGAL Revista de Ciències de la Catalunya Central

RIBA, O. et altri (1976).- Geografia Física dels Països Catalans, Edit. Ketres, 254 pàgines. Barcelona. 